Research Paper

\title{
Bactericidal effects of deep ultraviolet light-emitting diode for solutions during intravenous infusion
}

\author{
Sachiko Omotani ${ }^{1}$, Katsuji Tani ${ }^{1}$, Mai Aoe ${ }^{1}$, Seiji Esaki ${ }^{1}$, Katsuhito Nagai ${ }^{1}$, Yasutoshi Hatsuda ${ }^{1}$, Junji \\ Mukai $^{1}$, Hitomi Teramachi² ${ }^{2}$ and Michiaki Myotoku ${ }^{1 凶}$ \\ 1. Faculty of Pharmacy, Osaka Ohtani University; \\ 2. Gifu Pharmaceutical University. \\ $\triangle$ Corresponding author: Michiaki Myotoku, Faculty of Pharmacy, Osaka Ohtani University, 3-11-1, Nishikiori-kita, Tondabayashi-shi, Osaka 584-8540, Japan \\ E-mail: myoutom@osaka-ohtani.ac.jp \\ (c) Ivyspring International Publisher. This is an open access article distributed under the terms of the Creative Commons Attribution (CC BY-NC) license \\ (https://creativecommons.org/licenses/by-nc/4.0/). See http://ivyspring.com/terms for full terms and conditions.
}

Received: 2017.08.02; Accepted: 2017.11.13; Published: 2018.01.01

\begin{abstract}
Background: Ultraviolet irradiation is effectively used as a disinfection method for inactivating microorganisms.

Methods: We investigated the bactericidal effects by irradiation with a deep-ultraviolet light-emitting diode (DUV-LED) on the causative microorganisms of catheter related blood stream infection contaminating the solution for intravenous infusion. For irradiation, prototype modules for water disinfection with a DUV-LED were used. Experiments were conducted on five kinds of microorganisms. We examined the dependence of bactericidal action on eleven solutions. Administration sets were carried out three types.

Results: When the administration set JY-PB343L containing the infusion tube made of polybutadiene was used, the bactericidal action of the DUV-LED against all tested microorganisms in the physiological saline solutions was considered to be effective. We confirmed that the number of viable bacteria decreased in $5 \%$ glucose solution and electrolyte infusions with DUV-LED irradiation.

Conclusions: These results indicate that the DUV-LED irradiation has bactericidal effects in glucose infusion and electrolyte infusions by irradiating via a plasticizer-free polybutadiene administration set. We consider DUV-LED irradiation to be clinically applicable.
\end{abstract}

Key words: deep-ultraviolet light-emitting diode; bactericidal effect; catheter related blood stream infection.

\section{Introduction}

Catheter related blood stream infection (CRBSI) is defined as the presence of bacteremia originating from a peripheral vein catheter or a central venous catheter, and results in systemic infection. There are reports of surveillance and research on CRBSI caused by peripheral venous catheters and central venous catheters [1-6]. Routes for contamination of catheters are recognized as follows: direct contamination of the catheter or catheter hub by contact with hands contaminated with fluids or devices, and infusate contamination rarely leads to CRBSI [7].

As a countermeasure against CRBSI infection, care of the catheter hub is important [8-10], and hand hygiene and preparation under aseptic conditions are required [7]. Preparation of infusion fluid should be done under aseptic conditions because microbial contamination is one of the risks of bloodstream infection. However, in Japan, there are few hospitals where pharmacists prepare all infusions under aseptic conditions [11], and nurses often prepare infusions in wards not under aseptic conditions [12]. The nutrients contained in the infusion become a nutrient source for microorganisms. Bacillus megaterium and Bacillus cereus require amino acids for growth [13]. It is reported that B cereus, Serratia marcescens, Staphylococcus aureus and Candida albicans can grow in PPN solutions with or without lipid emulsion and multivitamins [14]. Escherichia coli, Pseudomonas aeruginosa and $S$ 
marcescens were reported to grow in electrolyte solution without glucose [15]. If microorganisms are mixed into the nutrient solutions, they can grow with amino acids, glucose and fatty acids in the solutions as a nutrition source, and lead to infection.

Ultraviolet (UV) irradiation is one of the physical methods of disinfection, and its bactericidal effects were reported [16-21]. For infection control, the effects of the pulsed xenon UV disinfection system for reduction of healthcare-associated pathogens in hospital rooms [22-24] and the effects of the stereotactic UV irradiating pass box have been demonstrated [25]. The bactericidal effects of UV irradiation in water have also been evaluated [26-27] and used in the industry.

Recently, deep ultraviolet light-emitting diodes (DUV-LEDs), which are underway in research and development, are battery-powered, compact and mercury free. DUV-LEDs are expected to be applied to a wide range of fields such as sterilization, air purification and resin curing. We investigated the bactericidal effects of irradiation with a DUV-LED that is compact and easy-to-use for causative microorganisms of CRBSI contamination during intravenous infusion.

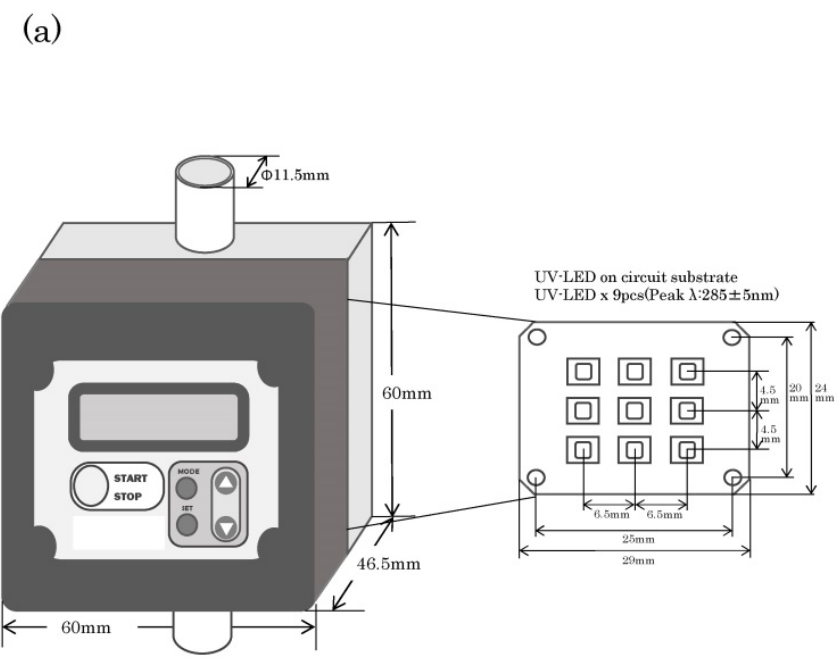

\section{Materials and Methods}

\section{The DUV-LED irradiation system}

For the DUV-LED irradiation system, the prototype module for water disinfection developed by NIKKISO CO., LTD. (Tokyo) was used. Figure 1 is an illustration of the DUV-LED irradiation module. The device operates at 24 VDC and contains 9 DUV-LEDs. It radiation in the UV spectrum of 275 to $285 \mathrm{~nm}$. The illuminance is $15 \mathrm{~mW} / \mathrm{cm}^{2}$ when 9 DUV-LEDs are used. The module performs sterilization directly on flowing water and irradiates from one direction. The caliber of the module is $\mathbf{1 1 . 5}$ $\mathrm{mm}$.

\section{Infusion system}

The infusion pump TE-131 (TERUMO Corp., Japan) was used to adjust the flow rate. Three kinds of administration sets were used: JY-PB343L (JMS Co., Ltd., Japan), JY-ND323L (JMS Co., Ltd., Japan) and JY-S343C23 (JMS Co., Ltd., Japan). JY-PB343L is made of polybutadiene (BR) and is plasticizer-free. JY-ND323L is made of polyvinyl chloride (PVC) using tris (2-ethylhexyl) trimellitate (TOTM) as a plasticizer. JY-S343C23 (JMS Co., Ltd., Japan) is made of PVC using diethylhexyl phthalate (DEHP) as a plasticizer. All are $2.5 \mathrm{~mm}$ in internal diameter and $3.9 \mathrm{~mm}$ in outer diameter.

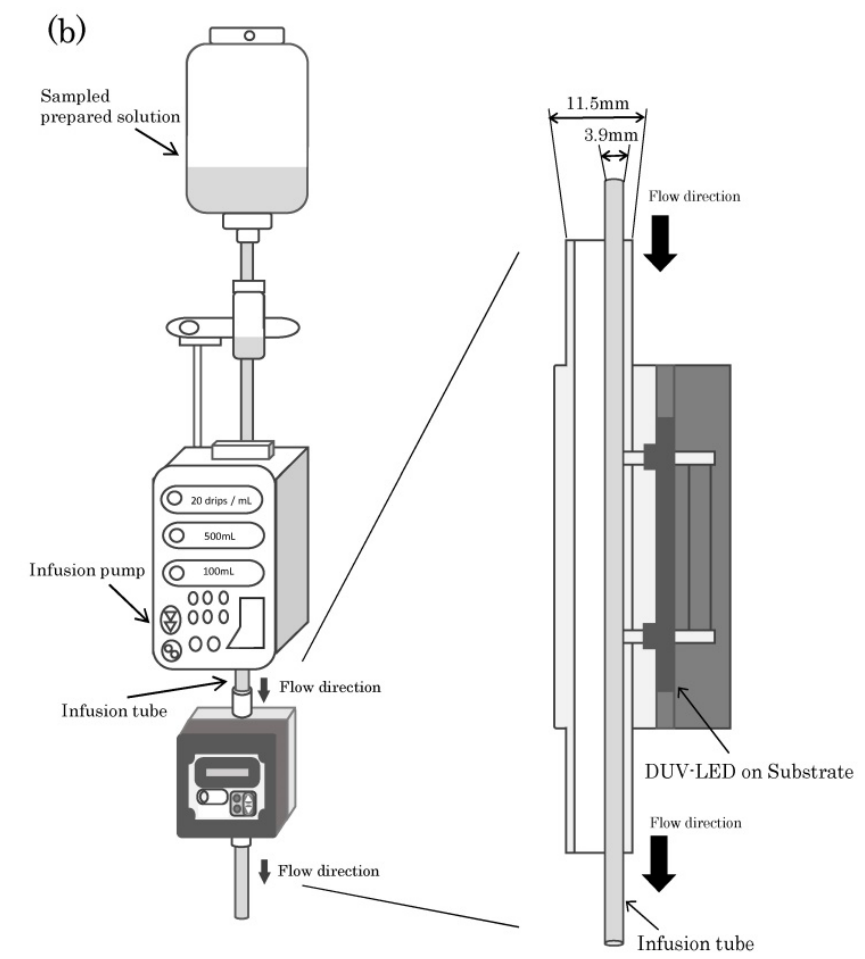

Figure 1. (a) Diagram of the prototype for water disinfection with a deep-ultraviolet light-emitting diode (DUV-LED) irradiation module. A description of the geometry of the module used in the experiments is included. (b) Diagram of the experiments with the DUV-LED irradiation module during intravenous infusion. 


\section{Microorganisms employed}

The standard strain was used for each microorganism, E coli W3110, P aeruginosa PAO001, $S$ marcescens NBRC 3046, $S$ aureus NBRC 12732 and $C$ albicans IFM 40009. E coli W3110 and $P$ aeruginosa PAO001 were used from laboratory stock. $S$ marcescens NBRC 3046 and S aureus NBRC 12732 were obtained from Biological Resource Center, National Institute of Technology and Evaluation. C albicans IFM 40009 was obtained from the National BioResource Project (http:/ / www.nbrp.jp/).

\section{Test solutions}

The compositions of solutions are shown in Table 1. We used glucose solution, electrolyte solutions, peripheral parenteral nutrition (PPN) solutions and total parenteral nutrition (TPN) solutions. For glucose solution, OTSUKA GLUCOSE INJECTION 5\% (Otsuka Pharmaceutical Factory, Inc., Japan) was used. For electrolyte solutions, OTSUKA NORMAL SALINE (Otsuka Pharmaceutical Factory, Inc., Japan), Lactec ${ }^{\circledR}$ (Otsuka Pharmaceutical Factory, Inc., Japan), Veen ${ }^{\circledR}$-D (Fuso Pharmaceutical Industries, Ltd., Japan), SOLDEM ${ }^{\circledR} 1$ (TERUMO Corp., Japan) and SOLDEM ${ }^{\circledR}$ 3A (TERUMO Corp., Japan) were used. PPN solutions containing 3\% commercial amino acids, $7.5 \%$ glucose solution and electrolytes with or without water soluble vitamins were used. They were AMINOFLUID ${ }^{\circledR}$ (Otsuka Pharmaceutical Factory, Inc., Japan) and BFLUID ${ }^{\circledR}$ (Otsuka Pharmaceutical Factory, Inc., Japan). TPN solutions containing 3\% commercial amino acids, $17.5 \%$ glucose solution and electrolytes with or without multivitamins and trace elements were used. They were PNTWIN ${ }^{\circledR}$ No.2 (Yoshindo Inc., Japan), NEOPAREN ${ }^{\circledR}$ No.2 (Otsuka Pharmaceutical Factory, Inc., Japan) and ELNEOPA ${ }^{\circledR}$ No.2 (Otsuka Pharmaceutical Factory, Inc., Japan).

\section{Culture methods and sampling}

All bacteria were inoculated into $5 \mathrm{~mL}$ of Luria-Bertani (LB) medium in sterile centrifuge tubes, and incubated at $37^{\circ} \mathrm{C}$ overnight. $C$ albicans was inoculated into $10 \mathrm{~mL}$ of Sabouraud broth in a sterile centrifuge tube, and incubated at $37^{\circ} \mathrm{C}$. After 12 hours, the cultures were transferred into $200 \mathrm{~mL}$ of fresh Sabouraud broth in sterile flasks, and incubated at $37^{\circ} \mathrm{C}$ overnight. Then, microbial cells were collected and washed with sterile phosphate-buffered saline (PBS) by centrifugation. A specified number of each test microorganism was added to each test solution, and the final microorganism concentration was adjusted to $10^{6}$ to $10^{7}$ colony-forming units $(\mathrm{CFU}) / \mathrm{mL}$. LB medium for bacteria was made by adding $5 \mathrm{~g}$ of yeast extract, $10 \mathrm{~g}$ of triptone, and $5 \mathrm{~g}$ of sodium chloride to $1 \mathrm{~L}$ of pure water. Sabouraud broth for $C$ albicans was made by adding $40 \mathrm{~g}$ of glucose and $10 \mathrm{~g}$ of peptone to $1 \mathrm{~L}$ of pure water.

\section{Description of DUV-LED irradiation method}

The flow rate of the sample solutions was adjusted with an infusion pump. The administration set was passed through the module and irradiated with the DUV-LED via the infusion tube. The flow rate was set at 30, 40, 50, 100 and $200 \mathrm{~mL} / \mathrm{hr}$. After conducting the irradiation experiment, the number of viable bacteria in the sample solutions was determined, and it was compared with the initial cell concentration. These experiments were performed at least twice.

\section{Enumeration of viable cells}

Each test solution sampled was serially diluted ten-fold with phosphate buffer. Each aliquot of the test solution samples for bacteria was spread on Standard agar (PEARLCORE NUTRIENT AGAR 'Eiken', Eiken Chemical Co., Ltd., Japan) plates in triple, and fungi was spread on Sabouraud agar plates. After 12 to 24 hours of incubation at $37^{\circ} \mathrm{C}$, colonies formed on the plates were counted, and concentration was calculated in solutions. Sabouraud agar for $C$ albicans was made by adding $40 \mathrm{~g}$ of glucose, $10 \mathrm{~g}$ of peptone and $15 \mathrm{~g}$ of agar to $1 \mathrm{~L}$ of pure water.

Table 1. The compositions of solutions

\begin{tabular}{|c|c|c|c|c|c|c|}
\hline & \multirow[t]{2}{*}{ Glucose } & \multirow[t]{2}{*}{ Electrolytic Solution } & \multirow[t]{2}{*}{ Amino Acids } & \multicolumn{2}{|l|}{ Vitamins } & \multirow[t]{2}{*}{ Trace Elements } \\
\hline & & & & Thiamine Chloride Hydrochloride & Multivitamins & \\
\hline OTSUKA GLUCOSE INJECTION 5\% & $\circ$ & - & - & - & - & - \\
\hline OTSUKA NORMAL SALINE & - & $\circ$ & - & - & - & - \\
\hline Lactec $^{\circledast}$ & - & $\circ$ & - & - & - & - \\
\hline Veen $^{\circledR}$-D & $\circ$ & $\circ$ & - & - & - & - \\
\hline SOLDEM $^{\otimes} 1$ & $\circ$ & $\circ$ & - & - & - & - \\
\hline SOLDEM $^{\otimes} 3 \mathrm{~A}$ & $\circ$ & $\circ$ & - & - & - & - \\
\hline AMINOFLUID $^{\circledast}$ & $\circ$ & $\circ$ & $\circ$ & - & - & - \\
\hline BFLUID $^{\circledast}$ & $\circ$ & $\circ$ & $\circ$ & $\circ$ & - & - \\
\hline PNTWIN ${ }^{\circledR}$ No.2 & $\circ$ & $\circ$ & $\circ$ & $\circ$ & $\circ$ & - \\
\hline NEOPAREN ${ }^{\circledR}$ No.2 & $\circ$ & $\circ$ & $\circ$ & $\circ$ & $\circ$ & - \\
\hline ELNEOPA ${ }^{\circledR}$ No.2 & $\circ$ & $\circ$ & $\circ$ & $\circ$ & $\circ$ & $\circ$ \\
\hline
\end{tabular}




\section{Results}

The bactericidal effects of DUV-LED with different infusion tubes on several microorganisms

Since the results of the experiments showed similar tendencies, one of them was indicated as the result. Table 2 shows the bactericidal effects of DUV-LED on several microorganisms with different administration sets. The number of viable microorganisms in samples prepared after DUV-LED irradiation was not different from that in initial cell controls. In all of the tested microorganisms, the number of viable microorganisms decreased when infusion using JY-PB343L was coupled with DUV-LED irradiation. The viable count of $E$ coli was $1.5 \times 10^{7} \mathrm{CFU} / \mathrm{mL}$ without DUV-LED irradiation, but it decreased to $9.9 \times 10^{6} \mathrm{CFU} / \mathrm{mL}$ when the infusion flow rate was $200 \mathrm{~mL} / \mathrm{hr}$ with DUV-LED irradiation. The viable count of $E$ coli decreased to $2.7 \times 10^{5} \mathrm{CFU} / \mathrm{mL}$ when the infusion flow rate was $50 \mathrm{~mL} / \mathrm{hr}$ with DUV-LED irradiation, and further decreased to $4.5 \times 10^{3} \mathrm{CFU} / \mathrm{mL}$ at a flow rate of $30 \mathrm{~mL} / \mathrm{hr}$ with DUV-LED irradiation. The viable count of $S$ aureus was $2.3 \times 10^{7} \mathrm{CFU} / \mathrm{mL}$ without DUV-LED irradiation, and it decreased to $8.7 \times 10^{1} \mathrm{CFU} / \mathrm{mL}$ when the infusion flow rate was $30 \mathrm{~mL} / \mathrm{hr}$ with DUV-LED irradiation. The viable count of $C$ albicans, a fungi, was $1.1 \times 10^{7} \mathrm{CFU} / \mathrm{mL}$ without DUV-LED irradiation, and it decreased to $7.5 \times 10^{4} \mathrm{CFU} / \mathrm{mL}$ when the infusion flow rate was $30 \mathrm{~mL} / \mathrm{hr}$ with DUV-LED irradiation. However, the reduction in fungi was lower than in bacteria.
On the other hand, none of the tested microorganisms decreased in number when JY-ND323L or JY-S343C23 was used with DUV-LED irradiation.

\section{The bactericidal effects of DUV-LED with different solutions}

Since the results of the experiments showed similar tendencies, one of them was indicated as the result. The bactericidal effects of DUV-LED with different solutions on $E$ coli are shown in Figure 2. The viable count of $E$ coli in samples prepared after DUV-LED irradiation was not different from the initial cell control. When $E$ coli in OTSUKA GLUCOSE INJECTION 5\% was irradiated with DUV-LED, E coli decreased post-irradiation. The viable count of $E$ coli was $1.1 \times 10^{7} \mathrm{CFU} / \mathrm{mL}$ without DUV-LED irradiation, and it decreased to $5.6 \times 10^{6} \mathrm{CFU} / \mathrm{mL}$ when the infusion flow rate was $200 \mathrm{~mL} / \mathrm{hr}$ with DUV-LED irradiation. It further decreased to $1.6 \times 10^{4} \mathrm{CFU} / \mathrm{mL}$ when the infusion flow rate was $30 \mathrm{~mL} / \mathrm{hr}$ with DUV-LED irradiation. As the flow rate got slower, the viable count of $E$ coli decreased. In the case of experiments using OTSUKA NORMAL SALINE, the viable count of $E$ coli was $1.5 \times 10^{7} \mathrm{CFU} / \mathrm{mL}$ without DUV-LED irradiation, and it decreased to $9.9 \times 10^{6}$ $\mathrm{CFU} / \mathrm{mL}$ when the infusion flow rate was $200 \mathrm{~mL} / \mathrm{hr}$ with DUV-LED irradiation. It further decreased to $4.5 \times 10^{3} \mathrm{CFU} / \mathrm{mL}$ when the infusion flow rate was 30 $\mathrm{mL} / \mathrm{hr}$ with DUV-LED irradiation. Similarly, in other electrolyte infusions, the number of viable bacteria when the infusion flow rate was $30 \mathrm{~mL} / \mathrm{hr}$ with DUV-LED irradiation compared with the number of viable bacteria without DUV-LED irradiation was found to be decreased by 3 orders of magnitude.

Table 2. Number of viable microorganism after irradiation (CFU)

\begin{tabular}{|c|c|c|c|c|c|c|}
\hline \multirow{2}{*}{$\begin{array}{l}\text { Administration sets } \\
\text { (infusion tube material) }\end{array}$} & \multirow{2}{*}{$\begin{array}{l}\text { Flow rate } \\
(\mathrm{mL} / \mathrm{hr})\end{array}$} & \multicolumn{5}{|c|}{ Microorganism } \\
\hline & & $\begin{array}{l}\text { Escherichia coli } \\
\text { W3110 }\end{array}$ & $\begin{array}{c}\text { Pseudomonas aeruginosa } \\
\text { PAO001 }\end{array}$ & $\begin{array}{l}\text { Serratia marcescens } \\
\quad \text { NBRC } 3046\end{array}$ & $\begin{array}{c}\text { Staphylococcus aureus } \\
\text { NBRC12732 }\end{array}$ & $\begin{array}{l}\text { Candida albicans } \\
\text { IFM40009 }\end{array}$ \\
\hline \multirow{6}{*}{$\begin{array}{l}\text { JY-PB343L } \\
\text { (polybutadiene, } \\
\text { plasticizer-free) }\end{array}$} & $\mathrm{C}$ & $1.5 \times 10^{7}$ & $8.5 \times 10^{6}$ & $9.3 \times 10^{6}$ & $2.3 \times 10^{7}$ & $1.1 \times 10^{7}$ \\
\hline & 200 & $9.9 \times 10^{6}$ & $8.3 \times 10^{5}$ & $3.4 \times 10^{6}$ & $1.0 \times 10^{7}$ & $1.0 \times 10^{7}$ \\
\hline & 100 & $3.4 \times 10^{6}$ & $2.1 \times 10^{4}$ & $1.4 \times 10^{6}$ & $2.0 \times 10^{6}$ & $6.0 \times 10^{6}$ \\
\hline & 50 & $2.7 \times 10^{5}$ & $6.6 \times 10^{2}$ & $7.1 \times 10^{4}$ & $3.1 \times 10^{3}$ & $6.2 \times 10^{5}$ \\
\hline & 40 & $1.5 \times 10^{4}$ & $6.2 \times 10^{2}$ & $1.4 \times 10^{4}$ & $1.1 \times 10^{3}$ & $1.2 \times 10^{5}$ \\
\hline & 30 & $4.5 \times 10^{3}$ & $1.2 \times 10^{3}$ & $5.1 \times 10^{2}$ & $8.7 \times 10^{1}$ & $7.5 \times 10^{4}$ \\
\hline \multirow{6}{*}{$\begin{array}{l}\text { JY-ND323L } \\
\text { (polyvinyl chloride, tris } \\
\text { (2-ethylhexyl) trimellitate } \\
\text { plasticizer) }\end{array}$} & $\mathrm{C}$ & $1.1 \times 10^{7}$ & $9.7 \times 10^{6}$ & $1.2 \times 10^{7}$ & $4.1 \times 10^{6}$ & $1.3 \times 10^{7}$ \\
\hline & 200 & $1.2 \times 10^{7}$ & $1.0 \times 10^{7}$ & $8.3 \times 10^{6}$ & $3.5 \times 10^{6}$ & $1.5 \times 10^{7}$ \\
\hline & 100 & $1.3 \times 10^{7}$ & $7.2 \times 10^{6}$ & $8.2 \times 10^{6}$ & $3.6 \times 10^{6}$ & $1.2 \times 10^{7}$ \\
\hline & 50 & $1.4 \times 10^{7}$ & $8.9 \times 10^{6}$ & $8.5 \times 10^{6}$ & $4.2 \times 10^{6}$ & $1.0 \times 10^{7}$ \\
\hline & 40 & $1.3 \times 10^{7}$ & $1.0 \times 10^{7}$ & $8.3 \times 10^{6}$ & $3.9 \times 10^{6}$ & $1.5 \times 10^{7}$ \\
\hline & 30 & $1.2 \times 10^{7}$ & $9.9 \times 10^{6}$ & $8.5 \times 10^{6}$ & $3.6 \times 10^{6}$ & $9.6 \times 10^{6}$ \\
\hline \multirow{6}{*}{$\begin{array}{l}\text { JY-S343C23 } \\
\text { (polyvinyl chloride, } \\
\text { diethylhexyl phthalate } \\
\text { plasticizer) }\end{array}$} & $\mathrm{C}$ & $1.1 \times 10^{7}$ & $1.3 \times 10^{7}$ & $9.1 \times 10^{6}$ & $5.3 \times 10^{6}$ & $1.4 \times 10^{7}$ \\
\hline & 200 & $9.5 \times 10^{6}$ & $1.1 \times 10^{7}$ & $9.3 \times 10^{6}$ & $5.3 \times 10^{6}$ & $1.5 \times 10^{7}$ \\
\hline & 100 & $1.0 \times 10^{7}$ & $1.2 \times 10^{7}$ & $9.3 \times 10^{6}$ & $6.0 \times 10^{6}$ & $1.7 \times 10^{7}$ \\
\hline & 50 & $9.1 \times 10^{6}$ & $1.0 \times 10^{7}$ & $8.7 \times 10^{6}$ & $5.1 \times 10^{6}$ & $1.2 \times 10^{7}$ \\
\hline & 40 & $1.0 \times 10^{7}$ & $1.0 \times 10^{7}$ & $1.0 \times 10^{7}$ & $5.3 \times 10^{6}$ & $1.2 \times 10^{7}$ \\
\hline & 30 & $9.6 \times 10^{6}$ & $9.2 \times 10^{6}$ & $9.4 \times 10^{6}$ & $5.4 \times 10^{6}$ & $1.5 \times 10^{7}$ \\
\hline
\end{tabular}

C; indicates the initial cell concentration in samples prepared. 
OTSUKA NORMAL SALINE

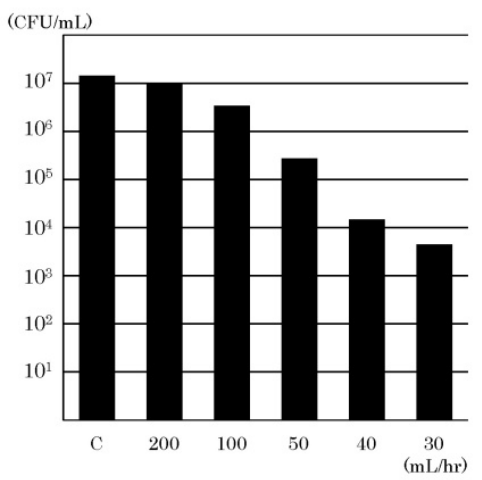

Veen $^{\circledR}-\mathrm{D}$

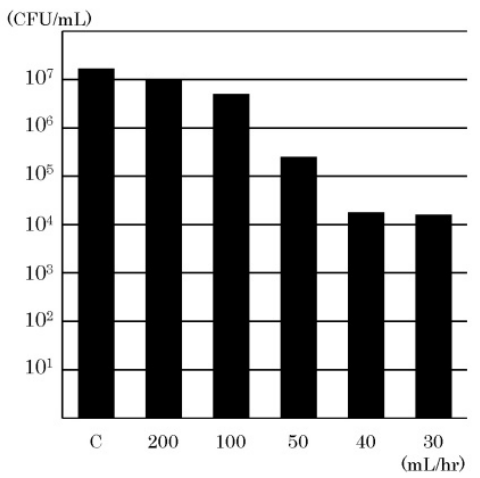

AMINOFLUID $^{(\mathbb{B}}$

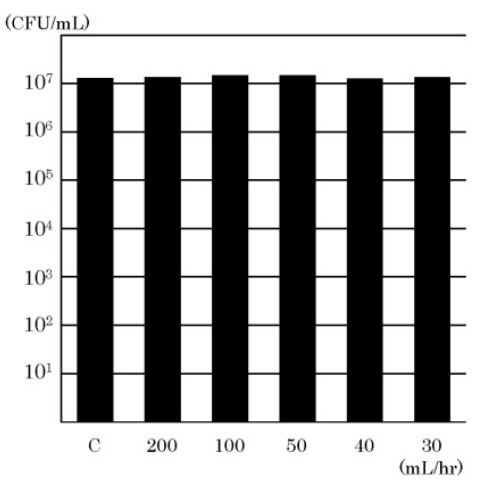

NEOPAREN ${ }^{\mathbb{B}}$ No.

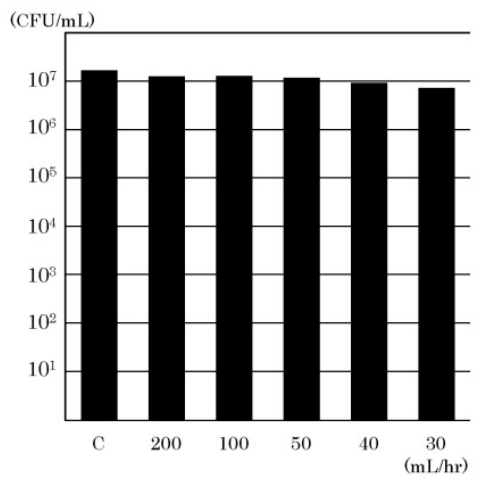

OTSUKA GLUCOSE INJECTION 5\%

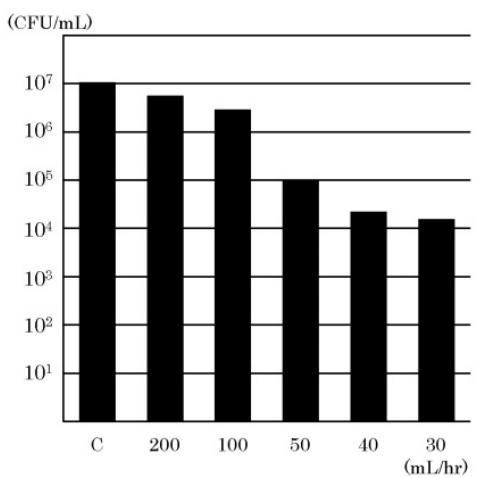

$\operatorname{SOLDEM}^{\circledR} 1$

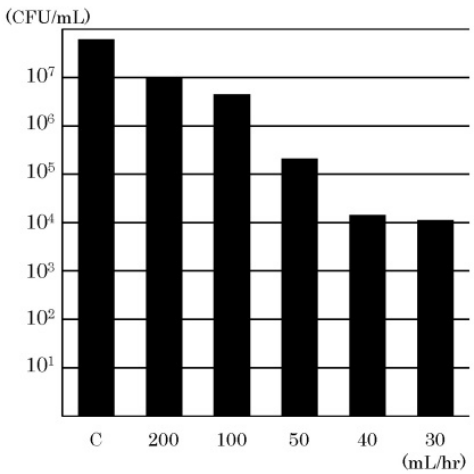

BFLUID $^{R}$

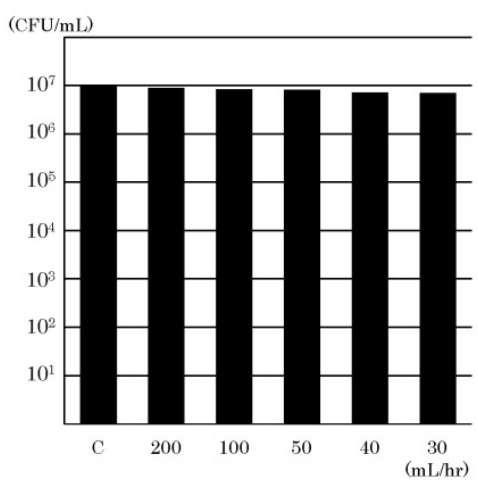

ELNEOPA $^{\circledR}$ No.2

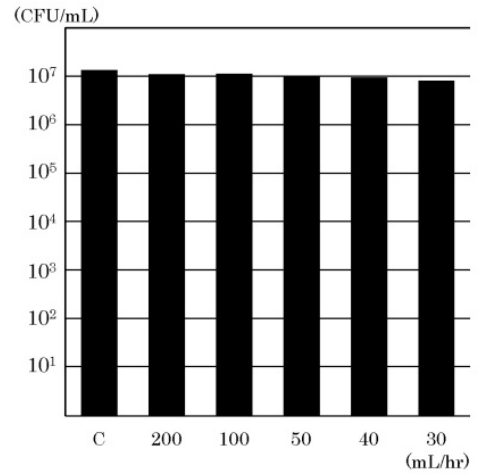

Lactec $^{\mathbb{R}}$

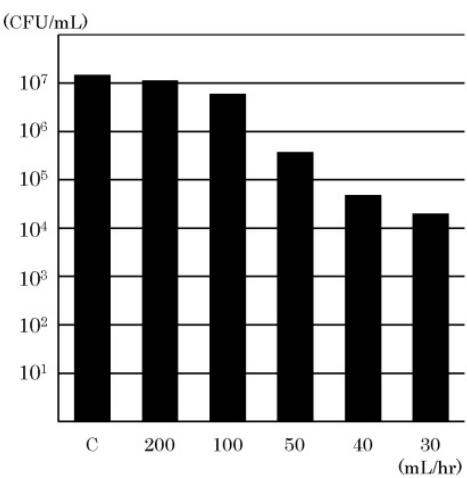

$\operatorname{SOLDEM}^{\mathbb{B}} 3 \mathrm{~A}$

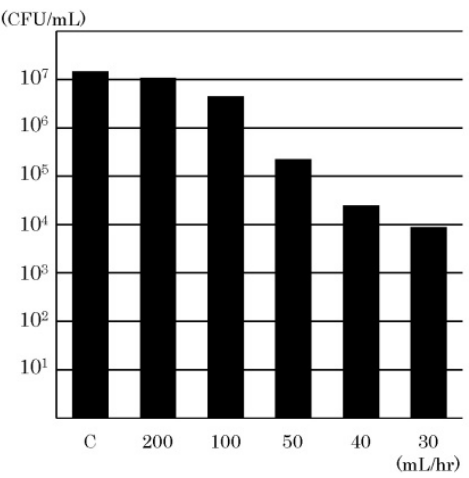

PNTWIN $^{\circledR}$ No.2

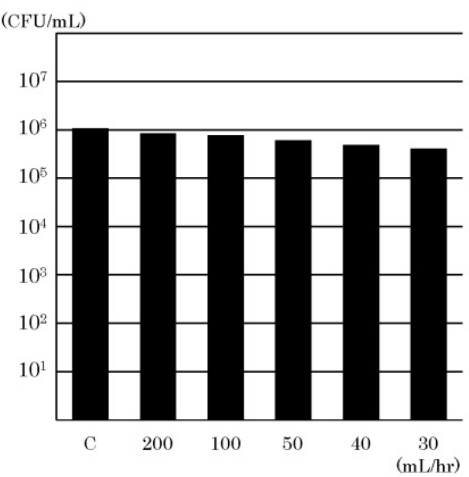

Figure 2. The bactericidal effects of the DUV-LED with different solutions on $E$. coli. The vertical axis of the graph indicates the number of viable bacteria in the solution. The horizontal axis of the graph indicates the initial cell concentration of viable bacteria in the solution or the flow rate at the time of irradiation. $\mathrm{C}$ indicates the initial cell concentration in the samples prepared. 
The viable count of $E$ coli in AMINOFLUID $^{\circledR}$, a PPN solution, was $1.3 \times 10^{7} \mathrm{CFU} / \mathrm{mL}$ without DUV-LED irradiation, and it did not decrease to $1.4 \times 10^{7} \mathrm{CFU} / \mathrm{mL}$ when the infusion flow rate was 30 $\mathrm{mL} / \mathrm{hr}$ with DUV-LED irradiation. In BFLUID ${ }^{\circledR}$, the viable count of $E$ coli was $1.0 \times 10^{7} \mathrm{CFU} / \mathrm{mL}$ without DUV-LED irradiation, but when the infusion flow rate was $30 \mathrm{~mL} / \mathrm{hr}$ with DUV-LED irradiation, it slightly decreased to $7.1 \times 10^{6} \mathrm{CFU} / \mathrm{mL}$. For PNTWIN ${ }^{\circledR}$ No.2, a TPN solution, E coli was $1.1 \times 10^{6} \mathrm{CFU} / \mathrm{mL}$ without DUV-LED irradiation, but when the infusion flow rate was $200 \mathrm{~mL} / \mathrm{hr}$ with DUV-LED irradiation, it decreased to $8.5 \times 10^{5} \mathrm{CFU} / \mathrm{mL}$. When the infusion flow rate was $30 \mathrm{~mL} / \mathrm{hr}$ with DUV-LED irradiation, it slightly decreased to $4.1 \times 10^{5} \mathrm{CFU} / \mathrm{mL}$. Likewise, with NEOPAREN ${ }^{\circledR}$ No.2 and ELNEOPA ${ }^{\circledR}$ No.2, E coli also decreased slightly.

\section{Discussion}

UV irradiation is effectively used as a disinfection method for inactivating microorganisms [16-27]. It is used for sterilizing food and medical fields. For the generation of UV light, a mercury lamp is generally used. However, mercury lamps have numerous wavelengths, require a large space, and the radiant heat is also great, such that the environmental burden is heavy. The DUV-LED developed in recent years has a short wavelength (255-350 nm), high sterilizing power among UV lights and it is possible to select a single wavelength. It requires only a small space, is lightweight, is capable of running at low voltage, is excellent in output controllability and high speed response, and can therefore be used conveniently. Thus, we examined the possibility of clinical application as a part of infection control by irradiating infusion lines with DUV-LED, which is installed as a system over infusion lines or in infusion pumps during infusion administration. For irradiation, a prototype module for water disinfection with DUV-LED, which emits a radiation in the UV spectrum of 275 to $285 \mathrm{~nm}$, was used. We investigated the bactericidal effects by irradiation with DUV-LED on the causative microorganisms of CRBSI contaminating the solutions for intravenous infusion.

In order to confirm the effects of sterilization by DUV-LED irradiation during intravenous infusion, we first investigated the dependency on the type of administration set. The number of viable microorganisms in solution was decreased by the DUV-LED irradiation for all of the tested bacteria using the administration set JY-PB343L. On the other hand, even when DUV-LED was employed using other administration sets, the viable count of the tested bacteria did not decrease. Polybutadiene is used in the infusion tube of administration set
JY-PB343L and it does not contain a plasticizer. The other infusion tubes in the administration sets contain a plasticizer because they are made of PVC. In JY-ND323L, TOTM is contained as a plasticizer and JY-S343C23 contains DEHP as a plasticizer. In these plasticizers, conjugated unsaturated bonds exist in the structural formula, and electrons in the molecule are changed from the ground state to the excited state by absorbing light in the UV part of the spectrum. Therefore, the amount of energy reaching the solution was considered to have been reduced and inactivation of the microorganisms did not occur. From the above, it was found that the effects of DUV-LED irradiation vary depending on the material of the infusion tube. By using an appropriate infusion tube, sterilizing effects using DUV-LED can be obtained when physiological saline is administered. Accordingly, when the administration set JY-PB343L was used, the bactericidal action of the DUV-LED against the microorganisms in the solutions was considered to be the most effective.

The bactericidal action against the microorganisms in the physiological saline solution was confirmed for all the tested microorganisms. However, as reported by Sullivan PK [28], the bactericidal action of UV irradiation against fungi was less effective than against bacteria. By irradiation with UV, adjacent bases in nucleic acid form a dimer and they cannot replicate, and DNA and RNA can be inactivated. In bacteria, the nucleoid is present in cell membranes. On the contrary, in fungi, as the chromosome is enveloped in the nuclear envelope, the bactericidal effects were inferior in fungi compared with in bacteria.

We examined the dependence of bactericidal action on the solution using the administration set JY-PB343L to confirm the bactericidal action on E coli by DUV-LED irradiation. The number of viable bacteria decreased with DUV-LED irradiation in OTSUKA GLUCOSE INJECTION 5\% and electrolyte infusions; therefore, we confirmed the bactericidal effects. However, in the case of PPN solutions or TPN solutions containing amino acids or vitamins, the number of viable bacteria did not decrease much compared with electrolyte infusion, and only weak sterilizing effects could be confirmed. As aromatic amino acids and some vitamins have conjugated unsaturated bonds, absorbance of light in the UV part of the spectrum is observed. Microbial inactivation likely occurred less as the UV energy received by the microorganisms decreased.

The prototype module for water disinfection with the DUV-LED used in this study was not developed for the purpose of sterilization during infusion administration, but was developed to flow 
water directly into the module with irradiation. In this study, we irradiated the infusion set adjacent to the DUV-LED in the module. As the diameter of the infusion tube used in this study differed greatly from the caliber of the irradiation system and installation was unstable, irradiation efficiency was not excellent. Irradiation can be performed more reliably by fitting the diameter of the irradiation system and the diameter of the infusion tube, and irradiating not only from one direction but also from the surroundings. As the nucleic acid of microorganisms has a maximum absorption in the vicinity of $265 \mathrm{~nm}$, it is possible that more marked sterilization effects can be obtained using a DUV-LED having the same wavelength. We can increase the irradiation dose by improving the system such that growth suppression and deactivation of microorganisms are more effective.

\section{Conclusion}

UV irradiation is one of the disinfection methods used in medical practice. DUV-LED irradiation is characterized by a short wavelength $(255-350 \mathrm{~nm})$, high sterilizing power, and it is compact, lightweight, battery-powered, and convenient. It is different from the conventional methods such as mercury lamps. These results indicate that DUV-LED irradiation has bactericidal effects in glucose and electrolyte infusions by irradiating via a plasticizer-free polybutadiene infusion tube. We consider DUV-LED irradiation to be clinically applicable.

\section{Competing Interests}

The authors have declared that no competing interest exists.

\section{References}

[1] Gahlot R, Nigam C, Kumar V, Yadav G, Anupurba S. Catheter-related bloodstream infections. Int J Crit Illn Inj Sci. 2014; 4:162-167.

[2] Sato A, Nakamura I, Fukushima S, Mizuno Y, Matsumoto T. Peripheral line-associated blood stream infection. Jpn J Infect Prev Control. 2015; 30:1-6.

[3] Pronovost P, Needham D, Berenholtz S, Sinopoli D, Chu H, Cosgrove S, et al. An intervention to decrease catheter-related bloodstream infections in the ICU. N Engl J Med. 2006; 355:2725-2732.

[4] Schulman J, Stricof R, Stevens TP, Horgan M, Gase K, Holzman IR, et al. Statewide NICU central-line-associated bloodstream infection rates decline after bundles and checklists. Pediatrics. 2011; 127:436-444.

[5] Mermel LA. Prevention of intravascular catheter-related infections. Ann Intern Med. 2000; 132:391-402.

[6] Matsumoto S, Suenaga H, Naito K, Sawazaki M, Hiramatsu T, Agata N. Management of suspected nosocomial infection: an audit of 19 hospitalized patients with septicemia caused by Bacillus species. Jpn J Infect Dis. 2000; 53:196-202.

[7] O'Grady NP, Alexander M, Burns LA, Dellinger EP, Garland J, Heard SO, et al. Guidelines for the prevention of intravascular catheter-related infections. Am J Infect Control. 2011; 39:S1-34.

[8] Cicalini S, Palmieri F, Petrosillo N. Clinical review: new technologies for prevention of intravascular catheter-related infections. Crit Care. 2004; 8:157-162.

[9] Akagi S, Matsubara H, Ogawa A, Kawai Y, Hisamatsu K, Miyaji K, et al. Prevention of catheter-related infections using a closed hub system in patients with pulmonary arterial hypertension. Circ J. 2007; 71:559-564.

[10] Sannoh S, Clones B, Munoz J, Montecalvo M, Parvez B. A multimodal approach to central venous catheter hub care can decrease catheter-related bloodstream infection. Am J Infect Control. 2010; 38:424-429.
[11] The Japanese Society of Hospital Pharmacists. Current situation survey of pharmaceutical department in 2015. J Jpn Soc Hosp Pharm. 2016; 52:761-832.

[12] Higashi E, Yamanouchi T, Ogasawara A, Mimura Y, Kawakami J, Adachi I. Questionnaire survey on handling of injections by hospital nurses. Jpn J Pharm Health Care Sci. 2005; 31:638-645.

[13] White PJ. The nutrition of Bacillus megaterium and Bacillus cereus. J Gen Microbiol. 1972; 71:505-514.

[14] Kuwahara T, Kaneda S, Shimono K, Inoue Y. Effects of lipid emulsion and multivitamins on the growth of microorganisms in peripheral parenteral nutrition solutions. Int J Med Sci. 2013; 10:1079-1084.

[15] Shiraishi T, Nakagawa Y. Evaluation of infusion fluids on outgrowth of several bacteria strains related to hospital-acquired infection. Jpn J Infect Prev Control. 2007; 22:165-169.

[16] Furuhashi M. Current status of ultraviolet irradiation research for sterilization. Jpn J med Instrum. 1990; 60:315-326.

[17] Conner-Kerr TA, Sullivan PK, Gaillard J, Franklin ME, Jones RM. The effects of ultraviolet radiation on antibiotic-resistant bacteria in vitro. Ostomy Wound Manage. 1998; 44:50-56.

[18] Thai TP, Keast DH, Campbell KE, Woodbury MG, Houghton PE. Effect of ultraviolet light $\mathrm{C}$ on bacterial colonization in chronic wounds. Ostomy Wound Manage. 2005; 51:32-45.

[19] Owens MU, Deal DR, Shoemaker MO, Knudson GB, Meszaros JE, Deal JL. High-dose ultraviolet $C$ light inactivates spores of Bacillus subtilis var. niger and Bacillus anthracis Sterne on non-reflective surfaces. Appl Biosaf. 2005; 10:240-247.

[20] Rao BK, Kumar P, Rao S, Gurung B. Bactericidal effect of ultraviolet C (UVC), direct and filtered through transparent plastic, on gram-positive cocci: an in vitro study. Ostomy Wound Manage. 2011; 57:46-52.

[21] Rao BK, Kumar P, Rao S, Jagdishchandra K, Suhasini P, Kamath A. Bactericidal effect of direct and filtered ultraviolet $C$ through transparent plastic sheet on gram negative bacilli-an in-vitro study. Int J Biomed Adv Res. 2012; 3:785-790.

[22] Nerandzic MM, Thota P, Sankar C T, Jencson A, Cadnum JL, Ray AJ, et al. Evaluation of a pulsed xenon ultraviolet disinfection system for reduction of healthcare-associated pathogens in hospital rooms. Infect Control Hosp Epidemiol. 2015; 36:192-197.

[23] Nagaraja A, Visintainer P, Haas JP, Menz J, Wormser GP, Montecalvo MA. Clostridium difficile infections before and during use of ultraviolet disinfection. Am J Infect Control. 2015; 43:940-945.

[24] Hosein I, Madeloso R, Nagaratnam W, Villamaria F, Stock E, Jinadatha C. Evaluation of a pulsed xenon ultraviolet light device for isolation room disinfection in a United Kingdom hospital. Am J Infect Control. 2016; 44:e157-161.

[25] Ogawa T, Matsuda $H$, Shiohata M, Miyachi $Y$, Ohno T, Nakamura M. Evaluation of a stereotactic (6-direction) ultraviolet irradiating pass box. Jikeikai Med J. 2011; 58:7-15.

[26] Lakretz A, Ron EZ, Mamane H. Biofouling control in water by various UVC wavelengths and doses. Biofouling. 2010; 26:257-267.

[27] Labas MD, Brandi RJ, Zalazar CS, Cassano AE. Water disinfection with UVC radiation and $\mathrm{H} 2 \mathrm{O} 2$. A comparative study. Photochem Photobiol Sci. 2009; 8:670-676.

[28] Sullivan PK, Conner-Kerr TA. A comparative study of the effects of UVC irradiation on select procaryotic and eucaryotic wound pathogens. Ostomy Wound Manage. 2000; 46:28-34 